\title{
PENINGKATAN KETERAMPILAN MENULIS KARANGAN NARASI SISWA KELAS III SDN 004 BATURIJAL HULU KECAMATAN PERANAP DENGAN MENERAPKAN MODEL PEMBELAJARAN THINK TALK WRITE
}

\author{
Aida Nur Santi \\ Sekolah Dasar Negeri 004 Baturijal Hulu, Kabupaten Indragiri Hulu, Indonesia \\ nursantiaida171@gmail.com
}

Received: July $26^{\text {st }}, 2020$

Revised: August $06^{\text {th }}, 2020$

Accepted: August $10^{\text {th }}, 2020$

\begin{abstract}
The problem in this research is the low skill of writing narrative essays for third grade students of SDN 004 Baturijal Hulu, from 27 students, 2 students with very skilled category; students with the skilled category 5 students; 10 students categorized as skilled enough; 10 students in the less skilled category. The method used in this research is classroom action research, which is conducted in 2 cycles which aims to improve the writing skills of third grade students of SDN 004 Baturijal Hulu by applying the Think Talk Write (TTW) learning model. The subjects of this study were third grade students of SDN 004 Baturijal Hulu. Data obtained through observation and tests. Meanwhile, the results of narrative essay writing skills after applying the Think Talk write learning model increased at UH1 with an average of 74.70 with a large increase from the basic score of $14.52 \%$ and the average UH II was 84.70 with a large increase in score. the base of $24.52 \%$. Based on the results of this study, it can be concluded that the implementation of the Think Talk Write (TTW) learning model can improve the narrative writing skills of grade III students of SDN 004 Baturijal Hulu.
\end{abstract}

Keyword: learning outcomes; narrative writing skills; think talk write.

\section{PENDAHULUAN}

Sekolah Dasar (SD) merupakan jenjang paling menentukan langkah awal siswa dalam menimba berbagai ilmu dan keterampilan. Di SD berbagai pelajaran dipelajari, mulai matematika, IPA, IPS sampai Bahasa Indonesia. Bahasa Indonesia merupakan salah satu mata pelajaran wajib yang di ajarkan di sekolah dasar. Bahasa Indonesia penting untuk dipelajari karena bertujuan agar setiap siswa dapat berkomunikasi secara efektif dan efesien, baik secara lisan maupun tertulis sesuai dengan kaidah Bahasa Indonesia yang baik dan benar. Oleh karena itu untuk mewujudkan suatu komunikasi yang efektif dan efisien, maka dibutuhkan keterampilan berbahasa yang harus dikuasai oleh setiap siswa. 
Dalam bahasa Indonesia dikenal adanya empat keterampilan berbahasa yang harus dimiliki oleh siswa, antara lain menyimak, berbicara, membaca dan menulis. Keterampilan menulis merupakan suatu keterampilan seseorang dalam menyampaikan pesan sesuai ide dan tata bahasa penulisnya dengan menggunakan media tulisan sebagai medianya. Keterampilan menulis dapat dikuasai oleh seseorang dengan latihan secara teratur. Menurut Megasari dalam Dalman (2014) menulis adalah proses penyampaian pikiran, angan-angan, perasaan, dalam bentuk tulisan yang bermakna. Kegiatan menulis salah satunya adalah menulis karangan narasi.

Menurut KBBI, karangan narasi merupakan suatu karangan yang berusaha mengisahkan suatu kejadian atau peristiwa sehingga tampak seolah-olah pembaca melihat atau mengalami sendiri peristiwa itu. Karangan narasi menyampaikan kepada pembaca mengenai urutan suatu kejadian dengan maksud memberi arti pada sebuah kejadian sehingga pembaca dapat memetik hikmah dari kejadian tersebut.

Sebagai salah satu kompetensi dasar yang harus dicapai siswa, keterampilan menulis karangan narasi tidak mudah. Kebanyakan siswa masih kesulitan ketika diminta untuk menulis karangan narasi. Kondisi ini pun terjadi dalam pembelajaran menulis karangan narasi di SDN 004 Baturijal Hulu.

Berdasarkan fakta di lapangan, Penulis selaku selaku guru di kelas III SDN 004 Baturijal ternyata keterampilan menulis karangan narasi pada mata pelajaran bahasa Indonesia masih rendah. Untuk lebih jelas dapat dilihat pada tabel 1.

Tabel 1. Data awal keterampilan menulis karangan narasi siswa

\begin{tabular}{|c|c|c|c|c|c|}
\hline \multirow[b]{2}{*}{ No } & \multirow{2}{*}{$\begin{array}{l}\text { Jumlah } \\
\text { siswa }\end{array}$} & \multicolumn{4}{|c|}{ Kategori } \\
\hline & & $\begin{array}{l}\text { Sangat } \\
\text { terampil }\end{array}$ & Terampil & $\begin{array}{l}\text { Cukup } \\
\text { terampil }\end{array}$ & $\begin{array}{l}\text { Kurang } \\
\text { terampil }\end{array}$ \\
\hline 1. & 27 & $\begin{array}{l}0 \text { siswa } \\
(0 \%)\end{array}$ & $\begin{array}{l}2 \text { siswa } \\
(7,40 \%)\end{array}$ & $\begin{array}{l}10 \text { siswa } \\
(37,04 \%)\end{array}$ & $\begin{array}{l}15 \text { siswa } \\
(55,56 \%)\end{array}$ \\
\hline
\end{tabular}


Berdasarkan Tabel di atas dapat diketahui masih banyaknya jumlah siswa yang belum terampil dalam menulis karangan narasi. Hal ini disebabkan oleh guru tidak memberi kesempatan untuk mengungkapkan ide-ide dalam pembelajaran karena pembelajaran masih berorientasi pada guru, sehingga siswa pasif dan siswa kurang mampu mengungkapkan ide/gagasannya baik secara lisan maupun tulisan, siswa juga sulit menjabarkan secara utuh objek yang dilihat, dirasa dan didengar dengan pilihan kata dan ejaan sesuai aturan tata bahasa yang benar.

Hal ini diduga merupakan salah satu penyebab terhambatnya kreativitas dan kemandirian siswa sehingga keterampilan menulis karangan narasi menjadi rendah, maka perlu diterapkan suatu sistem pembelajaran yang melibatkan peran siswa secara aktif dalam kegiatan belajar mengajar, guna meningkatkan keterampilan menulis karangan narasi. Salah satu model pembelajaran yang melibatkan peran siswa secara aktif adalah model pembelajaran Think Talk Write.

Model pembelajaran think talk write sangat cocok diterapkan pada keterampilan menulis karangan narasi karena model pembelajaran ini mencakup tiga keterampilan bahasa yang saling berkaitan satu sama lain yakni menyimak, berbicara dan menulis. Hal ini didukung dengan pendapat menurut Shoimin (2013) think talk write adalah suatu model pembelajaran yang bertujuan untuk melatih keterampilan peserta didik dalam menulis. Melalui model ini siswa dapat mengemukakan pemikirannya, saling bertukar pendapat, saling bekerja sama jika ada teman dalam kelompok yang mengalami kesulitan. Dengan pemilihan model ini, diharapkan pembelajaran yang terjadi dapat lebih bermakna dan memberi kesan yang kuat kepada siswa.

Dalam model pembelajaran Think Talk Write (TTW), ada beberapa langkahlangkah pembelajaran menurut Maftuh dan Nurmani dalam Hamdayama, J (2014) yaitu: Guru menjelaskan tentang Think Talk Write (TTW), kemudian guru menyampaikan tujuan pembelajaran. Selanjutnya guru menjelaskan sekilas tentang materi yang akan didiskusikan. Guru membentuk siswa dalam kelompok, setiap kelompok terdiri atas 3-5 orang, kemudian guru membagikan LKS pada setiap siswa. Siswa diminta untuk membaca soal LKS, kemudian memahami masalah secara individual dan dibuatkan catatan kecil (think). Guru 
mempersiapkan siswa berinteraksi dengan teman kelompok untuk membahas isi LKS (talk). Guru sebagai mediator lingkungan belajar. Kemudian guru mempersiapkan siswa menulis sendiri pengetahuan yang diperolehnya sebagai hasil kesepakatan dengan anggota kelompoknya (write). Guru meminta masingmasing kelompok mempresentasikan pekerjaannya dan meminta siswa dari kelompok lain untuk menanggapi jawaban dari kelompok lain. Model pembelajaran think talk write memiliki kelebihan diantaranya mempertajam seluruh keterampilan berpikir visual, mengembangkan pemecahan yang bermakna dalam rangka memahami materi ajar, dengan berinteraksi dan berdiskusi dengan kelompok akan melibatkan siswa secara aktif dalam belajar, membiasakan siswa berpikir dan berkomunikasi dengan teman,guru,dan bahkan dengan diri mereka sendiri

Dari latar belakang di atas, penulis melakukan Penelitian Tindakan Kelas dengan judul: "Peningkatan Keterampilan Menulis Karangan Narasi Siswa Kelas III SDN 004 Baturujal Hulu, kecamatan Peranap, dengan Menerapkan Model Pembelajaran Think Talk Write (TTW)".

\section{KAJIAN TEORITIS}

\section{Keterampilan Menulis Karangan Narasi}

Menurut Tarigan (2008) menulis merupakan suatu keterampilan berbahasa yang dipergunakan untuk berkomunikasi secara tidak langsung, tidak secara tatap muka dengan orang lain. Berarti melalui bahasa, seseorang dapat berkomunikasi dalam bentuk tulisan. Sedangkan Mulyati (2009) mengungkapkan bahwa menulis adalah kegiatan produktif dengan menggunakan tulisan. Menulis dapat dikatakan suatu ketrampilan berbahasa yang paling rumit diantara jenis-jenis ketrampilan berbahasa lainnya. Menulis memerlukan sejumlah potensi pendukung, yang untuk mencapainya diperlukan kesunguhan, kemauan keras, harus belajar dan berlatih dengan sungguh-sungguh dan terus menerus dalam waktu yang cukup lama. Menciptakan iklim budaya tulis akan mendorong seseorang menjadi lebih aktif, kreatif dan lebih cerdas.

Keraf (2010) mengungkapkan bahwa narasi adalah suatu bentuk wacana yang berusaha menggambarkan dengan sejelas-jelasnya kepada pembaca suatu 
peristiwa yang telah terjadi. Bentuk karangan ini berusaha mengisahkan suatu kejadian atau peristiwa yang seolah-olah pembaca dapat melihat dan dapat mengalami peristiwa itu. Unsur yang penting dalam narasi ini adalah perbuatan atau tindakan dan rangkaian waktu peristiwa itu terjadi. Ciri-ciri karangan narasi yaitu berupa cerita yang menggambarkan suatu tokoh atau peristiwa sehingga dapat membetuk suatu alur yang dapat dipahami, menurut Keraf (2000) ciri-ciri dari narasi antara lain: a) Menonjolkan unsur perbuatan atau tindakan. dirangkai dalam urutan waktu. b) berusaha menjawab pertanyaan, apa yang terjadi. c) ada konfiks.

Menulis karangan narasi memiliki langkah-langkah pengembangan antara lain: a) Menentukan tema atau amanat yang akan disampaikan; b) Menetapkan sasaran pembaca karangan narasi; c) Merancang peristiwa-peristiwa utama yang akan ditampilkan dalam skema luar; d) Membagi peristiwa utama dalam bagian awal, perkembangan, dan akhir cerita; e) Merinci peristiwa-peristiwa utama ke dalam detail-detail peristiwa sebagai pendukung cerita; f) Menyusun tokoh dan perwatakan, latar, dan sudut pandang.

\section{Model Pembelajaran Think Talk Write (TTW)}

Think Talk Write (TTW) merupakan model pembelajaran yang dikembang oleh huinker dan Laughlin. Menurut Huinker dan Laughlin (1996:82) menyatakan bahwa model pembelajaran Think Talk Write (TTW) membangun pemikiran, merefleksi, dan mengorganisasi ide, kemudian menguji ide tersebut sebelum peserta didik diharapkan untuk menulis. Alur model pembelajaran Think-TalkWrite (TTW) dimulai dari keterlibatan peserta didik dalam berpikir atau berdialog reflektif dengan dirinya sendiri, selanjutnya berbicara dan berbagi ide dengan temannya, sebelum peserta didik menulis.

Menurut Porter (1992) bahwa Think Talk Write (TTW) adalah pembelajaran dimana siswa diberikan kesempatan kepada peserta didik untuk memulai belajar dengan memahami pemasalahan terlebih dahulu, kemudian terlibat secara aktif dalam diskusi kelompok, dan akhirnya menuliskan dengan bahasa sendiri hasil belajar yang diperolehnya. 
Langkah-langkah model pembelajaran Think Talk Write (TTW) menurut Yamin dan Ansari (2008) meliputi: 1) Guru membagi teks bacaan berupa lembar aktivitas siswa yang memuat situasi masalah yang bersifat open ended dan petunjuk serta prosedur pelaksanaannya; 2) Siswa membaca teks dan membuat catatan hasil bacaan secara individual, untuk dibawa ke forum diskusi (think); 3) Siswa berinteraksi dan berkolaborasi dengan teman untuk membahas isi catatan (talk). Guru berperan sebagai mediator lingkungan belajar; 4) Siswa mengkonstruksikan sendiri pengetahuan sebagai hasil kolaborasi (write). Guru memantau dan mengevaluasi tingkat pemahaman siswa.

\section{METODE PENELITIAN}

Penelitian Tindakan Kelas ini dilaksanakan di kelas III SDN 004 Baturujal Hulu, kecamatan Peranap, Kabupaten Indragiri Hulu Riau. Waktu pelaksanaan penelitian ini pada semester genap tahun ajaran 2015/2016 yang dimulai dari bulan April sampai Mei 2016, dengan jumlah siswa 27 orang siswa dengan 14 siswa laki-laki dan 13 siswa perempuan. Peneliti terlibat langsung dalam perencanaan, pelaksanaan, pengamatan dan refeksi. Penelitian ini dilakukan dalam dua siklus dimana tiap siklus terdiri atas dua pertemuan.

Instrumen dalam penelitan ini yaitu perangkat pembelajaran yang terdiri dari silabus, RPP, dan LKS kemudian instrumen pengumpulan data yang terdiri dari lembar pengamatan aktivitas guru dan siswa dan tes keterampilan menulis karangan narasi.

Data diperoleh melalui lembar pengamatan aktivitas guru dan siswa, tes keterampilan menulis karangan narasi yang kemudian dianalisis.

Analisis data tentang aktivitas guru dan siswa didasarkan dari hasil lembar pengamatan selam proses pembelajaran berguna mengamati seluruh aktivitas yang dilakukan guru dan siswa dan dihitung dengan menggunakan rumus:

$N R=\frac{J S}{S M} \times 100 \%($ KTSP dalam Syahrilfuddin, $\mathrm{dkk}, 2011)$ 
Keterangan:

$\mathrm{NR}=$ Persentase rata-rata aktivitas guru/siswa

JS $=$ Jumlah skor aktivitas yang dilakukan

$\mathrm{SM}=$ Skor Maksimal yang di dapat dari aktivitas guru dan siswa

Kategori penilaian aktivitas belajar guru dan siswa tersebut dapat dilihat pada tabel berikut ini:

Tabel 2 Kategori aktivitas guru dan siswa

\begin{tabular}{cll}
\hline NO & Persentase (\%) Interval & \multicolumn{1}{c}{ Kategori } \\
\hline 1 & $81 \%-100 \%$ & Sangat Baik \\
2 & $61 \%-80 \%$ & Baik \\
3 & $51 \%-60 \%$ & Kurang Baik \\
4 & Kurang Dari 50\% & Sangat Tidak Baik \\
\hline
\end{tabular}

Keterampilan menulis karangan narasi siswa kelas III SDN 004 Baturujal Hulu, kecamatan Peranap, Kabupaten Indragiri Hulu Riau dalam menggunakan model pembelajaran Think Talk Write (TTW) dapat diketahui dengan menggunakan rubrik penilaian dengan indikator penilaian 1) kesesuaian isi dengan judul 2) Diksi 3) Penggunaan ejaan 4) kerapian. Tiap indikator diberi skala nilai 1 sampai 3, Dan menggunakan rumus sebagai berikut :

$$
S=\frac{R}{N} x 100 \text { (Purwanto, 2010) }
$$

Keterangan:

$\mathrm{S}=\quad$ Nilai yang diharapkan (dicari)

$\mathrm{R}=$ Jumlah skor dari indikator

$\mathrm{N}=$ Skor Maksimum

Untuk mengetahui interval dan kategori keterampilan menulis karangan narasi siswa dapat dilihat pada tabel berikut ini: 
Tabel 3. Interval penilaian keterampilan menulis karangan narasi siswa

\begin{tabular}{cc}
\hline Interval & Kategori \\
\hline $86-100$ & Sangat terampil \\
$76-85$ & Terampil \\
$56-75$ & Cukup terampil \\
$10-55$ & Kurang terampil \\
\hline
\end{tabular}

(Nurgiyantoro, 2013)

Untuk melihat keterampilan menulis karangan narasi yang terjadi dan sebelum diberi tindakan, peneliti menggunakan rumus sebagai berikut:

$$
P=\frac{\text { Posrate }- \text { Baserate }}{\text { Baserate }} \times 100 \%
$$

Keterangan:

$\mathrm{P} \quad=$ Persentase peningkatan

Posrate $=$ Nilai sesudah diberikan tindakan

Baserate $=$ Nilai sebelum tindakan $($ Aqib, 2011) .

\section{HASIL PENELITIAN}

\section{Tahap perencanaan}

Pada tahap ini peneliti sudah menyiapkan peralatan yang diperlukan antaralain perangkat pembelajaran: silabus, RPP, Lembar Kerja Siswa (LKS), Soal UH siklus I dan II dan instrumen pengumpulan data: lembar observasi aktivitas guru dan siswa untuk setiap pertemuan.

\section{Tahap pelaksanaan}

Proses pembelajaran yang memakai model pembelajaran think talk write dilakukan oleh peneliti setiap hari Selasa jam pertama dan hari Rabu jam kedua pada materi menulis karangan yang akan dilaksanakan peneliti untuk mengetahui peningkatan keterampilan menulis karangan narasi siswa. 
Pada hari Selasa, 12 April 2016 tepatnya pertemuan pertama disiklus 1 dengan jumlah siswa hadir 27 orang yaitu hadir semua. Proses pembelajaran dilaksanakan berdasarkan RPP ke-1 yaitu dengan materi menulis karangan berdasarkan gambar seri yang diawali dengan menyusun kalimat berdasarkan gambar seri.

Pada langkah pertama menjelaskan tentang think talk write, aktifitas pada langkah yang pertama guru memulainya dengan mengucapkan salam, lalu meminta kepada ketua kelas memimpin teman-temannya untuk bersiap mambaca do'a bersama, lalu guru mengabsen kehadiran siswa. Guru melakukan appersepsi dengan melihatkan 3 gambar, setelah itu guru memberikan pertanyaan "gambar apa ini?" untuk dijawab para siswa. Kemudian guru meluruskan jawaban siswa dan menjelaskan sedikit tentang model pembelajaran think talk write. Pada langkah kedua, guru menyampaikan tujuan pembelajaran kepada siswa yaitu siswa dapat menyusun kalimat berdasarkan gambar sehingga menjadi sebuah karangan narasi dengan memperhatikan penggunaan ejaan.

Pada langkah ketiga menjelaskan materi pelajaran, guru menyampaikan hal yang penting dalam materi pembelajaran tentang menulis karangan berdasarkan gambar seri. Saat guru menjelaskan, kebanyakan siswa berbicara, dan kurang fokus menerima pelajaran yang disampaikan guru. Pada langkah keempat, setelah guru memberikan materi pembelajaran siswa dimasukkan kedalam beberapa kelompok yang beranggotakan 3 orang. Saat dibagikan kelompok siswa kelihatan kebingungan dan belum mengerti. Pada langkah kelima membagi LKS pada siswa, guru memberikan LKS yang harus dikerjakan siswa sebelum mengerjakan LKS guru menjelaskan langkah kerja yang harus dikerjakan siswa, pada langkah keenam guru meminta siswa untuk memikirkan dan memahami lembar kerja tersebut secara individu dengan membuat catatan kecil (think), setelah menulis ide dari gambar dengan sendiri, langkah ketujuh guru meminta siswa untuk berbagi informasi tentang pemahamannya mengenai gambar yang telah disajikan (talk). Saat mengerjakan LKS, masih kelihatan siswa belum mengerti dan kurang paham dengan tugas yang diberikan. Pada langkah ketujuh mempersiapkan siswa menulis hasil diskusi, Pada saat mendiskusikan ide guru 
meminta siswa secara berkelompok untuk menuliskan hasil karangan berdasarkan kesepakatan bersama (write). Langkah kedelapan mempresentasikan hasil karangan, Setelah siswa selesai menulis hasil karangan, guru meminta dari masing-masing kelompok untuk membacakan hasil karangan tersebut. Langkah kesembilan meminta siswa untuk menanggapi karangan yang dibaca, pada saat membacakan hasil karangan, siswa diberikan kesempatan untuk menanggapi karangan dari kelompok penyaji. Ketika temannya membacakan hasil diskusi kelompok, ada sebagian siswa rebut, tidak fokus dan hanya main-main dengan teman sebelahnya.

Pada kegiatan akhir pembelajaran, guru bersama siswa merefleksi materi yang telah dipelajari yaitu materi menulis karangan berdasarkan gambar seri. Setelah merefleksi materi, kemudian guru dan siswa menjawab bersama jawaban yang benar dari LKS. Setelah itu guru mengukur tingkat penguasaan siswa secara individu dengan memberikan evaluasi tentang menulis karangan narasi berdasarkan gambar seri yang telah disediakan.

Pada pertemuan pertama siklus 1 ini, proses pembe lajaran masih belum sesuai dengan apa yang direncanakan dari awal. Siswa masih terlihat kaku saat proses pembelajaran, masih ada beberapa siswa yang rebut, belum paham, masih main-main. Guru masih belum bisa menguasai keadaan kelas dan belum terbiasa menerapkan model pembelajaran think talk write selama proses pembelajaran.

Pada hari Rabu, 20 April 2016 tepatnya pertemuan kedua disiklus 1 dengan jumlah siswa yang hadir 27 orang atau hadir semua. Materi pembelajaran yang dibahas adalah menulis kalimat pokok sesuai gambar menjadi sebuah karangan narasi dan sesuai langkah-langkah pembelajaran think talk write.

Pada pertemuan kedua siklus $1 \mathrm{ini}$, proses pembelajaran sudah mulai membaik dari pertemuan yang sebelumnya. Siswa mulai aktif saat proses pembelajaran, walaupun masih ada beberapa siswa yang berbicara dan masih bermain-main dalam belajar. Guru sudah mulai terbiasa menerapkan model ini, walaupun saat mengajar masih ada kekurangan. Saat membimbing siswa masih kurang memberi motivasi kepada siswa saat belajar. 
Setelah 2 kali pertemuan pada siklus 1, dilakukan ulangan harian siklus 1 pada hari Jum'at, 29 April 2016. Ulangan harian siklus pertama dilakukan selama 2x35 menit. Dengan soal mengenai menulis karangan narasi berdasarkan gambar seri. Kegiatan ulangan harian siklus I diawali guru dengan membagikan lembar soal dan lembar jawaban kepada masing masing siswa. Selanjutnya guru mempersilahkan siswa untuk mengerjakan soal tersebut secara individu. Guru meminta siswa belajar dengan sungguh-sungguh dan teliti. Setelah selesai mengerjakan ulangan harian siklus I, siswa diminta mengumpulkannya. Kemudian guru mengoreksi hasil karangan siswa untuk menegetahui tingkat keterampilan menulis karangan narasi siswa dengan panduan rubrik sebagai acuan dalam penilaian karangan narasi, adapun aspek yang dinilai dari menulis karangan narasi adalah pilihan kata (diksi), isi karangan, penggunaan ejaan, tanda baca dan kerapian. Pelaksanaan ulangan harian siklus pertama berjalan dengan tertib dan lancar.

Pertemuan pertama siklus 2 dilakukan pada Selasa 10 Mei 2016, dengan jumlah siswa yang hadir 27 orang atau hadir semua. Proses pembelajaran dilaksanakan berdasarkan RPP ke-3 yaitu dengan materi menulis karangan dengan gambar tunggal.

Pada langkah pertama menjelaskan tentang think talk write, aktifitas pada langkah yang pertama guru memulainya dengan mengucapkan salam, lalu meminta kepada ketua kelas memimpin teman-temannya untuk bersiap mambaca do'a bersama, lalu guru mengabsen kehadiran siswa. Guru melakukan apersepsi dengan menggunakan media gambar dan mengajukan pertanyaan, guru memberikan kesempatan kepada siswa untuk menjawab pertanyaan. Beberapa siswa menjawab, kemudian guru meluruskan jawaban siswa dan pada langkah kedua guru menyampaikan tujuan pembelajaran kepada siswa yaitu siswa dapat menulis karangan berdasarkan gambar tunggal dengan menggunakan pilihan kata dan ejaan yang tepat serta memberi motivasi kepada siswa.

Pada langkah ketiga guru menyampaikan hal panting yang ada didalam materi pembelajaran tentang menulis karangan narasi berdasarkan gambar 
tunggal. Saat guru menjelaskan, siswa memperhatikan guru menjelaskan dengan sekssama. Setelah menyampaikan materi, masuk ke langkah keempat guru meminta siswa untuk membentuk kelompok yang beranggotakan 3 orang. Siswa langsung duduk dengan kelompoknya masing-masing. Langkah kelima guru memberikan LKS yang harus dikerjakan siswa. Sebelum mengerjakan LKS, guru memberikan arahan mengenai cara pengerjaan LKS, setelah itu guru meminta siswa untuk memikirkan dan memahami lembar kerja tersebut secara individu dengan membuat catatan kecil (think), setelah menulis ide dari gambar dengan sendiri, langkah keenam guru meminta siswa untuk berbagi informasi tentang pemahamannya mengenai gambar yang telah disajikan (talk). Saat mengerjakan LKS guru membimbing tiap-tiap kelompok yang masih kurang mengerti dengan tugas yang diberikan pada langkah tujuh. Pada saat berdiskusi guru meminta siswa secara berkelompok untuk menuliskan hasil karangan berdasarkan kesepakatan bersama (write). Setelah siswa selesai menulis hasil karangan, pada langkah kedelapan guru meminta dari masing-masing kelompok untuk membacakan hasil karangan tersebut. Langkah kesembilan pada saat presentasi dilakukan, siswa diberikan kesempatan untuk menanggapi hasil presentasi dari kelompok penyaji. Ada beberapa siswa yang menanggapi dan guru menjelaskan dan membenarkan tanggapan siswa.

Pada kegiatan akhir pembelajaran, guru bersama siswa merefleksi materi yang telah diperlajari yaitu tentang menulis karangan narasi menggunakan gambar tunggal. Setelah selesai merefleksi, kemudian guru melakukan penilaian hasil pembelajaran. Guru mengukur tingkat keterampilan siswa secara individu dengan memberi evaluasi tentang menulis karangan menggunakan gambar tunggal.

Pada pertemuan pertama siklus 2 ini, proses pembelajaran sudah membaik dibandingkan pertemuan yang sebelumnya. Siswa aktif saat proses pembelajaran, guru sudah terbiasa menerapkan model pembelajaran ini, guru sudan bisa membimbing siswa dalam berdiskusi kelompok, dan guru bisa memanajemen waktu dengan baik. 
Pertemuan kedua siklus 2 dilakukan pada hari Rabu, 18 Mei 2016 dengan jumlah siswa yang hadir 27 orang atau hadir semua. Proses pembelajaran dilaksanakan berdasarkan RPP ke-4 yaitu dengan materi menulis karangan sederhana dan mengikuti langkah-langkah model pembelajaran think talk write.

\section{Tahap pengamatan}

Berdasarkan pengamatan observer yang diperoleh dari 2 kali pertemuan pada siklus 1 , hasilnya sudah baik, namun disamping memiliki kelebihan masih ada kelemahan yang peneliti temukan. Kelebihan yang peneliti temukan selama proses pembelajaran yaitu guru lebih mudah membimbing siswa, kegiatan pembelajaran di kelas lebih didominasi siswa, sebagian siswa mulai berani mngungkapkan pendapat. Sedangkan kekurangan-kekurangan yang peneliti temukan selama proses pembelajaran adalah ketika guru menyampaikan langkah model pembelajaran think talk write siswa masih terlihat kebingungan, ketika guru menjelaskan materi, masih ada beberapa siswa yang ribut dan kurang memperhatikan penjelasan dari guru, ketika mengkondisikan siswa dalam kelompok masih ada siswa yang mengalami penolakan dalam kelompok, pada saat diskusi kelompok masih ada siswa yang pasif dan masih ada siswa yang mendominasi pengerjaan tugas kelompok. Dalam membacakan hasil kerja kelompok, masih ada siswa yang tidak fokus pada siswa yang membacakan hasil kerja kelompok di depan kelas. Pada pelaksanaan tindakan siklus 2, aktivitas guru dan siswa mengalami peningkatan dibandingkan pada siklus 1. peningkatan ini bias tercapai karena guru dan siswa sudah memahami langkah-langkah pembelajaran menggunakan model think talk write.

\section{Tahap refleksi}

Dari hasil refleksi siklus 1, maka perbaikan yang akan peneliti lakukan untuk diterapkan pada siklus selanjutnya adalah memberikan pengertian kepada siswa agar sungguh-sungguh bekerjasama dengan kelompoknya dalam menyelesaikan pertanyaan yang terdapat dalam LKS agar seluruh siswa bisa memahami materi pembelajaran. Guru memberikan penjelasan kepada siswa tentang langkah- 
langkah pembelajaran think talk write, agar dalam mengerjakan LKS siswa lebih memahami kapan berfikir secara individu dan kapan berfikir secara kelompoknya. Sedangkan pada siklus 2 ini sudah berjalan lancar dibandingkan dengan siklus pertama. Pada siklus 2 ini, siswa juga sudah terbiasa dengan penerapan model pembelajaran think talk write sehingga pada saat diberikan LKS untuk dikerjakan, dilanjutkan dengan mendiskusikannya dengan kelompok dan siswa membacakan hasil karangan kedepan kelas, semua siswa sangat aktif dan bekerjasama. Siswa terlihat tidak lagi merasa canggung dengan diterapkan model pembelajaran ini. Bahkan siswa merasa senang, karena model pembelajaran ini dapat memberikan mereka kebebasan dalam mengeluarkan pendapat. Penelitian tidak dilanjutkan ke siklus 3 , karena pada siklus 2 data hasil keterampilan menulis siswa mengalami peningkatan sehingga penelitian hanya sampai 2 siklus saja.

\section{Hasil penelitian}

Hasil keterampilan menulis karangan narasi sebelum ditentukan berdasarkan ulangan akhir siklus I dan ulangan akhir siklus II dapat dilihat pada tabel berikut :

Tabel 4. Hasil skor dasar sebelum keterampilan menulis karangan narasi

\begin{tabular}{llll}
\hline No & Inteval & Kategori & Jumlah siswa \\
\hline $\mathbf{1}$ & $86-100$ & Sangat Terampil & 2 Siswa \\
$\mathbf{2}$ & $76-85$ & Terampil & 5 Siswa \\
$\mathbf{3}$ & $56-75$ & Cukup Terampil & 10 Siswa \\
$\mathbf{4}$ & $10-55$ & Kurang Terampil & 10 Siswa \\
Jumlah Siswa & & 27 Siswa \\
\hline
\end{tabular}

Tabel 4 menunjukkan bahwa hasil keterampilan menulis karangan narasi sebelum tindakan dengan jumlah siswa 27, siswa sangat terampil 2 orang, siswa dengan kategori terampil 5 orang, 10 orang dengan kategori cukup terampil dan 10 orang dengan kategori kurang terampil. Dari data tersebut dapat disimpulkan 
bahwa sebagian besar siswa masih kurang terampil dalam menulis karangan narasi.

Adapun hasil keterampilan menulis karangan narasi setelah menggunakan model pembelajaran think talk write dapat dilihat pada tabel dibawah .

Tabel 5. Hasil keterampilan menulis karangan narasi siswa setelah menggunakan model pembelajaran think talk write siklus I dan siklus II

\begin{tabular}{lllll}
\hline No & Inteval & Kategori & UH 1 & UH 2 \\
\hline $\mathbf{1}$ & $86-100$ & Sangat Terampil & 7 Siswa & 10 Siswa \\
$\mathbf{2}$ & $76-85$ & Terampil & 10 Siswa & 11Siswa \\
$\mathbf{3}$ & $56-75$ & Cukup Terampil & 6 Siswa & 5 Siswa \\
$\mathbf{4}$ & $10-55$ & Kurang Terampil & 4 Siswa & 1 Siswa \\
\multirow{2}{*}{ Jumlah Siswa } & & 27 Siswa & 27 Siswa \\
\hline
\end{tabular}

Dapat dilihat dari tabel 5 di atas terjadi peningkatan pada ulangan harian siklus I ke ulangan harian siklus II, siswa yang mendapat kategori sangat terampil pada siklus I ada 7 siswa kemudian meningkat menjadi 10 siswa, pada kategori terampil pada siklus I ada 10 orang kemudian meningkat pada siklus II menjadi 11 siswa, kategori cukup terampil pada siklus I ada 6 siswa, dan pada siklus II ada 5 orang siswa, dengan kategori kurang terampil pada siklus I ada 4 siswa dan pada siklus II ada 1 siswa.

Untuk mengetahui peningkatan keterampilan menulis karangan narasi siswa pada siklus I dan siklus II dengan menggunakan model pembelajaran think talk write pada siswa kelas III SDN 004 Baturijal Hulu dilakukan analisis terhadap hasil ulangan akhir siklus untuk mengetahui hasil keterampilan menulis karangan siswa secara individu. Untuk mengetahui peningkatan keterampilan menulis karangan narasi dapat dilihat pada tabel 6 . 
Tabel 6. Peningkatan keterampilan menulis karangan narasi pada skor dasar siklus I dan Siklus II

\begin{tabular}{|c|c|c|c|c|}
\hline \multirow[t]{2}{*}{ No } & \multirow{2}{*}{$\begin{array}{l}\text { Keterampilan } \\
\text { menulis siswa }\end{array}$} & \multirow[t]{2}{*}{ Rata-rata } & \multicolumn{2}{|c|}{$\begin{array}{l}\text { Peningkatan keterampilan } \\
\text { menulis }\end{array}$} \\
\hline & & & SD-UH 1 & SD-UH II \\
\hline 1 & Skor dasar & 60,18 & & \\
\hline \multirow[t]{2}{*}{2} & Ulangan Harian Siklus & 74,70 & $14,52 \%$ & \\
\hline & I & & & $24,52 \%$ \\
\hline 3 & $\begin{array}{l}\text { Ulangan harian siklus } \\
\text { II }\end{array}$ & 84,70 & & \\
\hline
\end{tabular}

Dari table 6 terlihat bahwa ada peningkatan keterampilan menulis karangan narasi siswa kelas III SD negeri 004 Baturijal Hulu setelah diterapkannya model pembelajaran think talk write yang dimulai dari skor dasar, siklus I dan siklus II. Pada skor dasar nilai rata-rata siswa 60,18 karena selama ini proses pembelajaran yang dilakukan guru tidak memberi kesempatan siswa untuk mengungkapkan pendapat sendiri, sehingga siswa menjadi pasif dan siswa kurang mampu berpikir kritis, sehingga siswa menjadi susah untuk mendeskripsikan apa yang dilihat, dirasa dan didengar dengan pemilihan tata bahasa yang benar. Setelah diberikan tindakan oleh guru dengan menerapkan model pembelajaran think talk write terlihat bahwa keterampilan menulis karangan narasi siswa meningkat daripada sebelum menggunakan model pembelajaran think talk write. Dari nilai rata-rata skor dasar meningkat pada siklus I sebesar $14,52 \%$ menjadi 74,70 . Sedangkan pada siklus II nilai rata-rata menjadi 84,70 dengan peningkatan sebesar $24,52 \%$. Pembelajaran dengan penerapan model think talk write dapat meningkatkan keterampilan menulis karangan narasi siswa kelas III SD Negeri 004 Baturijal Hulu. 


\section{PEMBAHASAN}

Hasil keterampilan menulis karangan narasi siswa adanya peningkatan setelah diterapkannya model think talk write yang dimulai dari skor dasar, siklus I dan siklus II. Pada skor dasar nilai rata-rata siswa 60,18 Karena selama ini proses pembelajaran yang dilakukan masih berorientasi pada guru, sehingga siswa kurang mampu mengungkapkan ide baik secara lisan maupun tulisan. Siswa lebih banyak diam sewaktu proses pembelajaran berlangsung sehingga guru tidak mendapatkan hasil yang optimal dalam proses pembelajaran.

Setelah diberikan tindakan oleh guru dengan menerapkan model pembelajaran think talk write terlihat bahwa hasil belajar siswa meningkat dari pada sebelum menggunakan model pembelajaran Think Talk Write. Dari nilai ratarata skor dasar meningkat pada siklus I menjadi 74,70 dengan peningkatan sebesar $14,52 \%$. Sedangkan pada siklus II nilai rata rata juga meningkat menjadi 84,70 dengan peningkatan sebesar 24,52\%. Huiker dan Laughin (dalam Hamdayama, 2014) mengatakan bahwa model ini pada dasarnya dibangun melalui berpikir, berbicara dan menulis. Selain itu Yamin dan Ansari (2012); Ain SQ dan Mulyani EA (2018); Rahmi dkk (2018) juga menyebutkan bahwa model think talk write (TW) dapat menumbuh kembangkan kemampuan pemecahan masalah. Dalam Manuaba (2013) mengatakan dalam berinteraksi sosial, manusia berkomunikasi dengan menggunakan wahana bahasa yang dikontruksi secara kontekstual dan yang telah disepakati, baik dalam tataran struktur maupun makna bahasa. Sehingga model ini dapat meningkatkan siswa dalam menuangkan ide, kreatif, dan aktif dalam proses pembelajaran. Sejalan dengan itu dengan model ini sangat baik dalam meningkatkan keterampilan menulis karangan narasi siswa.

Model pembelajaran think talk write dimulai dari keterlibatan siswa dalam berpikir kritis sehingga siswa mampu mengungkapkan ide kepada temannya sebelum ditulis. Suasana seperti ini lebih efektif apabila dilakukan dalam 3-5 siswa/kelompok. Dalam kelompok ini siswa diminta membaca, membuat catatan kecil, menjelaskan melalui mendengarkan dan membagi ide bersama teman kemudian menyampaikan melalui tulisan. Proses pembelajaran yang seperti itulah 
sehingga menyebabkan hasil keterampilan menulis karangan narasi siswa mengingkat dimulai dari proses think (berpikir) kemudian talk (berbicara) dan write (menulis). Dengan demikian hipotesis tindakan ysang diajukan yaitu jika diterapkan model pembelajaran think talk write (TTW) maka dapat meningkatkan keterampilan menulis karangan narasi siswa kelas III SDN 004 Baturijal Hulu dapat diterima.

\section{SIMPULAN DAN REKOMENDASI}

Berdasarkan data hasil penelitian yang telah dilaksanakan dengan penerapan model pembelajaran Think Talk Write (TTW), dapat disimpulkan bahwa model pembelajaran think talk write dapat meningkatkan keterampilan menulis karangan narasi siswa kelas III SDN 004 Baturijal Hulu. Hal ini terbukti dari hasil ulangan yang dilakukan pada siklus I dengan rata-rata 74,70 meningkat pada siklus II menjadi 84,70 .

Rekomendasi penelitian ini ialah hasil penelitian ini dapat dijadikan salah satu alternatif model pembelajaran pada mata pembelajaran bahasa Indonesia dalam upaya meningkatkan keterampilan menulis karangan narasi siswa. Dan juga bagi peneliti selanjutnya, dapat digunakan sebagai referensi dalam menyelesaikan penelitian yang berhubungan dengan model pembelajaran think talk write, sehingga dapat memberi sumbangan yang baik bagi sekolah dalam memperbaiki proses pembelajaran dan dapat meningkatkan kualitas pendidikan.

\section{DAFTAR PUSTAKA}

Ain, S. Q., \& Mulyani, E. A. (2018). Peningkatan Kemampuan Pemahaman Matematis Melalui Pembelajaran dengan Strategi Think Talk Write (TTW) Di Sekolah Dasar. Tunjuk Ajar Jurnal Penelitian IImu Pendidikan, 1(1).

Ansari, B. I. (2003). Menumbuhkembangkan Kemampuan Pemahaman dan Komunikasi Matematik Melalui Strategi Think-Talk-Write. Disertasi Doktor Pada FPMIPA UPI Bandung: Tidak Diterbitkan.

Aqib, Z. (2011). Penelitian Tindakan Kelas Untuk Guru, SMP, SMA, SMK. Bandung: Yrama Widya.

Dalman. (2016). Keterampilan Menulis. Jakarta: Rajawali Pers. 
Hamdayama, J. (2014). Model Dan Metode Pembelajaran Kreatif Dan Berkarakter. Bogor: Ghalia Indonesia.

Huinker, D. \& Laughlin, C. (1996). Talk Your Way Into Writing. Dalam Communication in Mathematics K-12 and Beyond, 1996 Year Book. The National Counsil of Teacher of Mathematics.

Keraf, G. (2000). Diksi dan Gaya Bahasa. Jakarta: Rinneka Cipta.

Keraf, G. (2010). Argumentasi dan Narasi. Jakarta: Gramedia.

Manuaba, P. (2013). Politik Bahasa Sastra: Strategi Bahasa Ekspresif Produksi Karya Sastra dalam Prosiding Seminar Nasional Politik Bahasa dan Bahasa Polotik. Fakultas Ilmu Budaya. Universitas Airlangga. Surabaya. 25-26 Oktober.

Miftahul, H. (2014). Model-Model Pengajaran dan Pembelajaran. Yogyakarta: Pustaka Pelajar.

Mulyati, Y. Dkk. (2009). Ketrampilan Berbahasa Indonesia SD. Jakarta: Universitas Terbuka

Nurgiyantoro, B. (2014). Penilaian Pembelajaran Bahasa Berbasis Kompetensi. Yogyakarta: BPFE-YOGYAKARTA

Porter, B. (1992). Quantum Learning. Bandung : Penerbit Kaifa.

Purwanto, N. (2010). Prinsip-Prinsip Dan Teknik Evaluasi Pengajaran. Bandung: Remaja Rosda Karya.

Rahmi, E., dkk. (2018). Penerapan model pembelajaran kooperatif tipe talking stick dapat meningkatkan hasil belajar IPS siswa kelas VB SDIT Insan Utama Pekanbaru. Tunjuk Ajar: Jurnal Penelitian Ilmu Pendidikan, 1(2), 94103.

Syahrilfuddin, dkk. (2011). Penelitian Tindakan Kelas. Pekanbaru: Cendikia Insani.

Tarigan, H G. (2008). Berbicara Sebagai Suatu Keterampilan Berbahasa. Bandung: Angkasa

Yamin \& Ansari. (2008). Taktik Mengembangkan kemampuan Individual Siswa. Jakarta: Putra Grafika

Yamin \& Ansari. (2012). Taktik Mengembangkan kemampuan Individual Siswa. Jakarta: Referensi. 